\title{
PENGELOLAAN SUMBERDAYA BATUBARA INDONESIA DAN PROSPEKNYA DALAM PASAR GLOBAL DENGAN ANALISIS SWOT
}

\author{
Management of Indonesian Coal Resources and Its Prospects in the \\ Global Market Using SWOT Analysis
}

\author{
HARTA HARYADI \\ Pusat Penelitian dan Pengembangan Teknologi Mineral dan Batubara \\ Jalan Jend. Sudirman 623 Bandung 40211 \\ Telp. (022) 6030483, Fax. (022) 6003373 \\ e-mail: harta.haryadi@esdm.go.id
}

\begin{abstract}
ABSTRAK
Dalam pengelolaan sumber daya batubara diperlukan kebijakan dan terobosan baru agar sektor batubara Indonesia memilliki daya saing yang tinggi dalam rangka menghadapi pasar global batubara. Studi ini bertujuan untuk menganalisis kondisi sektor pertambangan batubara Indonesia dalam kancah persaingan global, yang anggotanya sudah mencapai 164 negara pada 2019. Studi ini menggunakan pendekatan analisis Strength, Weakness, Opportunities and Threat (SWOT). Hasil analisis menunjukkan, pertama, diperlukan penguasaan teknologi dan pendayagunaan sumber daya manusia yang berkualitas dan profesional. Kedua, meningkatkan ketersediaan infrastruktur pendukung untuk mengatasi kendala supply energi serta peningkatan kualitas batubara agar berdaya saing tinggi dalam rangka meraih peluang pasar dalam dan luar negeri. Hasil analisis dapat dijadikan masukan bagi pemerintah dalam upaya meningkatkan daya saing sektor batubara dalam menghadapi pasar global dan terpenuhinya kebutuhan batubara untuk industri dalam negeri.
\end{abstract}

Kata kunci: batubara, kekuatan, kelemahan, peluang, globalisasi ekonomi.

\begin{abstract}
In managing coal resources, new policies and breakthroughs are needed so that the Indonesian coal sector has high competitiveness in facing the global coal market. This study aims to analyze the condition of the Indonesian coal mining sector in global competition that has 164 member countries in 2019. This study uses an analysis approach of Strength, Weakness, Opportunities and Threat (SWOT). The results of the analysis show that, first, it requires a mastery of technology and utilization of professional human resources. Second, increase the availability of supporting infrastructure to overcome energy supply constraints and improve the quality of coal to be highly competitive in order to seize market opportunities at home and abroad. The results of the analysis can be used as input for the government in an effort to improve the competitiveness of the coal sector in facing the global market and the fulfillment of coal needs for the domestic industry.
\end{abstract}

Keywords: coal, strengths, weaknesses, opportunities, economic globalization. 


\section{PENDAHULUAN}

Globalisasi ekonomi dengan sistem pasar bebas dunia merupakan sistem perekonomian yang harus dilalui dan harus diikuti oleh seluruh negara di dunia untuk menciptakan kesejahteraan perekonomian dunia (Nurhaidah dan Musa, 2015). Negara yang tidak mempersiapkan diri dan tidak mengembangkan perekonomiannya ke dalam sistem perekonomian global tersebut akan menghadapi resiko kemunduran (Zaroni, 2015). Dalam konteks pengelolaan sumber daya batubara, Indonesia memerlukan kebijakan dan terobosan baru agar sektor batubara memilliki daya saing tinggi dan mampu memasuki dan menghadapi pasar global batubara.

Sampai saat ini produksi tambang batubara Indonesia sebagian besar ditujukan untuk pasar ekspor khususnya ke Cina. Di satu sisi ekspor batubara akan menghasilkan devisa, namun di sisi lain kebutuhan batubara untuk kepentingan domestik juga harus terpenuhi. Di sini terjadi tarik menarik antara kepentingan ekspor dan pemenuhan kebutuhan domestik.

Sebagian besar output energi dunia dan produksi listrik dihasilkan oleh Pembangkit Listrik Tenaga Uap (PLTU) karena tersedianya batubara dalam jumlah besar. Proses ekstraksinya relatif mudah dan murah, demikian juga dengan biaya infrastrukturnya yang lebih murah dibandingkan dengan sumberdaya energi fosil (BP, 2018).

Permintaan batubara kualitas rendah dari Cina, India, Jepang dan Korea sangat besar karena banyak PLTU baru yang dibangun untuk mensuplai kebutuhan listrik industrinya yang besar (Sagawa, 2019). Indonesia memiliki cadangan batubara kualitas menengah dan rendah yang cukup besar, dengan harga kompetitif di pasar internasional. Hal ini antara lain disebabkan biaya produksi upah tenaga kerja Indonesia yang rendah. Di samping migas, batubara sangat dibutuhkan kontribusinya untuk mendukung pendapatan negara (APBN) berupa devisa yang cukup besar.

Permintaan terhadap batubara Indonesia sangat dipengaruhi oleh kondisi pasar global, khususnya Cina sebagai konsumen batubara terbesar dunia. Mengingat sebagian besar batubara Indonesia ditujukan untuk pasar ekspor, maka produksi dan ekspor batubara Indonesia akan dipengaruhi harga di pasar global.

Menurut data Direktorat Jenderal Mineral dan Batubara (2018), cadangan batubara Indonesia mencapai 24,24 miliar ton dan produksi 2017 sebesar 461 juta ton. Apabila tingkat produksi saat ini diteruskan serta tidak ada eksplorasi dan penemuan cadangan baru maka batubara Indonesia diperkirakan akan habis kira-kira dalam waktu 53 tahun mendatang. Di kemudian hari kondisi energi Indonesia akan menghadapi ketidakpastian karena menipisnya supply batubara, sementara dibutuhkan energi yang besar untuk pembangunan.

Sebelum menghadapi situasi buruk pemerintah perlu meninjau kembali isu strategis dari persoalan batubara. Isu strategis sebagaimana dimaksud dapat dilakukan dengan analisis Strengths, Weaknesses, Opportunites dan Threats (SWOT). Analisis tersebut dapat dimanfaatkan antara lain untuk pengelolaan sumber daya batubara yang efektif dan efisien, prospek meraih peluang di pasar global, serta strategi untuk memenuhi kebutuhan dalam negeri. Di samping itu hasil analisis SWOT dapat dijadikan masukan kebijakan untuk menjadikan batubara sebagai bahan galian strategis karena bernilai tambah tinggi, serta menjadi motor penggerak perekonomian regional dan nasional (Nawatmi, 2011).

Terbentuknya Organisasi Perdagangan Dunia (World Trade Organization/WTO) pada 1 Januari 1995 bertolak dari pemikiran bahwa diperlukan badan tingkat tinggi untuk mengawasi bekerjanya sistem perdagangan multilateral dan untuk menjamin agar negaranegara anggota WTO mematuhi peraturanperaturan yang telah disepakati serta memenuhi kewajiban-kewajibannya (Jamilus, 2017). WTO memiliki tujuan antara lain: mencapai perdagangan internasional yang stabil dan menghindari kebijakan perdagangan yang merugikan; meningkatkan volume perdagangan dunia; mengembangkan sistem perdagangan multilateral; meningkatkan pemanfaatan sumber kekayaan dunia untuk meningkatkan produksi dan transaksi jual beli barang; dan menyatukan kegiatan-kegiatan konsumsi, ekonomi produksi dan investasi antar negara di seluruh penjuru dunia (Kusumawardhana dan Zulkarnain, 2016). Hingga 2019 anggota WTO berjumlah 164 
negara dan 22 negara pengamat (Firmansyah dan Hendra, 2015). Keikutsertaan Indonesia dalam organisasi perjanjian perdagangan bebas WTO, membawa konsekuensi bahwa perdagangan antara negara di seluruh dunia dilakukan tanpa hambatan apapun seperti tarif, pajak ekspor dan impor. Harga barang-barang menjadi lebih murah dengan kualitas makin tinggi (Azzarqa dan Basuki, 2014).

Dengan berlakunya WTO akan terjadi peningkatan persaingan sektor pertambangan batubara di pasar domestik negara-negara anggotanya (Agustiwi, 2016). Pengusaha pertambangan batubara yang tidak efisien akan memiliki daya saing rendah dan sulit memasarkan produknya. Dengan adanya WTO, pengusaha sektor pertambangan batubara dengan tingkat produksi yang efisien akan memiliki daya saing tinggi serta mampu menguasai pasar global, sekaligus menyumbang devisa yang besar serta mendorong pertumbuhan ekonomi negaranya.

Pada umumnya, adanya pasar bebas akan memberikan keuntungan ekonomi bagi negara anggota WTO, di antaranya : Pertama, tidak ada tarif impor dan tidak ada pembatasan (kuota) dan hambatan impor lainnya sehingga akan meningkatkan daya saing di pasar domestik maupun pasar ekspor; harga bahan baku dan input lainnya menjadi murah (Triono, 2013). Kedua, pengaruh eksternalitas melalui alih ilmu pengetahuan, teknologi, manajemen, organisasi dan metode produksi yang lebih efisien dari negara anggota WTO yang lebih maju ke negara berkembang sesama anggota (Mahsun, 2013). Ketiga, akses untuk mendapatkan barang modal atau teknologi modern menjadi lebih mudah.

Negara anggota WTO yang belum mampu mengembangkan teknologinya sendiri, tidak akan ketinggalan karena bisa diperoleh dari anggota negara WTO yang teknologinya sudah maju (Putra dan Saraswati, 2016). Setiap negara anggota WTO bisa memperluas pasar dan variasi produk yang dapat diproduksi di dalam negeri berdasarkan spesialisasi (Suprijanto, 2011), alokasi sumber daya produksi yang menjadi lebih efisien dan produktif (Sumitro, 2015). Menurut Widayanto (2016), pasar bebas bagi Indonesia dapat meningkatkan kualitas produk dalam negeri; membuka peluang bagi investor berproduksi di Indonesia; meningkatkan devisa dari ekspor.
Selain memberi keuntungan, WTO memberikan ancaman atau dampak negatif, antara lain: supply bahan baku untuk kebutuhan dalam negeri berkurang karena lebih banyak diekspor. Hal ini berdampak terhadap perusahaanperusahaan di dalam negeri (Parimin dan Putra, 2018). Selain itu, Indonesia menjadi tergantung pada negara lain; persaingan antara produk dalam negeri dan luar negeri yang semakin ketat (Sujati, 2018). Apabila kalah dalam persaingan maka hal tersebut akan berdampak terhadap menurunnya produksi dalam negeri yang pada gilirannya akan berpengaruh terhadap perekonomian makro nasional.

Menurut Badan Pusat Statistik (2018), perdagangan bebas belum berdampak signifikan terhadap kinerja perusahaan di Indonesia. Artinya sampai saat ini belum terlihat ancaman serius. Jumlah unit usaha dan kontribusi output terhadap pembentukan produk domestik bruto (PDB) terus bertambah setiap tahun.

Menurut Almahdy dan Imam Mustaqim (2011), ada dua permasalahan yang akan dihadapi oleh sektor pertambangan batubara Indonesia dalam menghadapi WTO. Pertama, kemampuan batubara dalam negeri bersaing dengan batubara impor. Kedua, kemampuan memanfaatkan peluang dari perdagangan bebas untuk menguasai pasar. Terbentuknya WTO, merupakan momentum untuk menghasilkan batubara berkualitas tinggi agar dapat menguasai pasar global.

Salah satu upaya yang dilakukan pemerintah untuk mendukung sektor batubara, yaitu dikeluarkannya Undang Undang No. 4 Tahun 2009 Tentang Pertambangan Mineral dan Batubara, yang mewajibkan seluruh pengusaha sektor pertambangan batubara melakukan pengolahan dan pemurnian sebelum diekspor, agar diperoleh manfaat ekonomi yang besar bagi pengusaha, bagi negara dan masyarakat, serta memiliki daya saing yang tinggi di pasar ekspor. UU tersebut telah diperbaharui dengan terbitnya UU No. 3 Tahun 2020.

Sampai saat ini sektor pertambangan batubara Indonesia belum memperlihatkan kemajuan, ditandai dengan lambatnya para pengusaha melaksanakan program hilirisasi batubara, sementara kinerja perusahaan batubara cenderung menurun ditandai dengan banyaknya perusahaan yang berhenti dari 
rencana kegiatannya (Siregar dan Sunarti, 2017). Menurut Hidayat dan Rahmat (2018), kalau kondisi ini tidak segera diperbaiki, diprediksi sektor pertambangan batubara Indonesia tidak akan mampu bersaing di pasar dunia.

Pada lingkungan internal dan eksternal, ke depan, sektor pertambangan batubara diprediksi akan menghadapi perubahan dan ketidakpastian (Istiqomah dan Andriyanto, 2017). Pemerintah, khususnya Kementerian ESDM sebagai regulator sektor batubara perlu merencanakan dan merumuskan strategi bersaing menghadapi negara-negara produsen batubara dunia lainnya sebelum permasalahan sektor batubara semakin besar (Anwar dan Utami, 2012). Pemerintah perlu memingkatkan kinerja dan daya saing produk dan jasa sektor batubara di pasar global dengan didukung strategi yang tepat sesuai dengan perubahan lingkungan strategis (Gunawan, 2013).

Salah satu alat analisis untuk merumuskan strategi pencapaian sasaran tersebut adalah analisis SWOT. Dengan analisis SWOT ini diharapkan dapat dirumuskan berbagai alternatif strategi yang perlu dilakukan sebagai masukan dalam penyusunan kebijakan sektor ESDM khususnya sektor batubara dalam menghadapi pasar global sekaligus bisa menguasai pasarnya (Bahari, Leksono dan Ismiyah, 2018). Pendekatan SWOT dalam pengelolaan sumber daya batubara Indonesia serta prospeknya dalam pasar global dimaksudkan untuk menganalisis kondisi internal perusahaan batubara (kekuatan dan kelemahan) dan menelaah kondisi eksternal (peluang dan ancaman), dalam kerangka visi dan misi perusahaan (Rahmayati, 2015; Subaktilah, Kuswardani dan Yuwanti, 2018). Sasarannya adalah agar organisasi atau perusahaan batubara mampu memanfaatkan informasi perubahan untuk mendapatkan keunggulan kompetitifnya di masa depan dalam rangka menguasai peluang pasar global dan pemenuhan kebutuhan batubara industri dalam negeri (Tamara, 2016). Selanjutnya seluruh kekuatan, kelemahan, peluang dan ancaman di sektor batubara diintegrasikan ke dalam sebuah tabel data sehingga faktor-faktor internal dan eksternal dari pertambangan batubara dapat dianalisis (Subaktilah, Kuswardani dan Yuwanti, 2018).

\section{METODE}

Penelitian ini menggunakan metodologi deskriptif kualitatif yaitu metode yang digunakan untuk meneliti obyek, kondisi, sistem perencanaan serta peristiwa yang kemungkinan akan terjadi di masa depan, melalui pengamatan langsung, observasi, wawancara dan pencarian dokumen ke beberapa Dinas Energi dan Sumber Daya Mineral (ESDM) dan beberapa perusahaan tambang batubara sebagai responden, serta studi literatur dari berbagai penelitian yang terkait. Dari hasil identifikasi tersebut maka dapat diketahui faktor internal (kekuatan dan kelemahan sektor batubara); faktor-faktor eksternal (peluang dan ancaman bagi sektor batubara), faktor-faktor keunggulan pertambangan batubara Indonesia di pasar global. Selanjutnya seluruh faktor-faktor kekuatan, kelemahan, peluang dan ancaman dari pertambangan batubara dianalisis (Wicaksono, 2018).

Setelah indikator-indikator SWOT diidentifikasi, langkah pertama adalah menentukan bobot, rating, dan score bobot. Bobot ditentukan berdasarkan tingkat kepentingan dengan skala 1 sampai 4 ( 1 = tidak penting, 2 = cukup penting, 3 = penting, 4 = sangat penting). Langkah kedua menjumlahkan bobot kekuatan dan bobot kelemahan, sehingga diperoleh total bobot. Selanjutnya dihitung bobot relatif untuk masingmasing indikator dengan cara membagi masingmasing bobot dengan total bobot dari kekuatan dan kelemahan, sehingga hasil total nilai bobot relatif tersebut bila dijumlahkan menjadi 1 atau $100 \%$. Dengan cara yang sama dihitung bobot relatif untuk peluang dan ancaman, sehingga total nilai bobot tersebut menjadi 1 atau $100 \%$. Langkah ketiga adalah menentukan rating, yaitu analisis yang memengaruhi organisasi, selanjutnya, bobot dikalikan dengan rating.

Nilai rating untuk kekuatan dan peluang diberi nilai 1 sampai 4 :

a. Diberi nilai 4, kalau indikator tersebut lebih baik dibanding pesaing.

b. Diberi nilai 3 kalau indikator kinerjanya cukup baik dibanding pesaing.

c. Diberi nilai 2 kalau indikator kinerjanya sama dengan pesaing utama.

d. Diberi nilai 1 kalau indikator kinerjanya semakin menurun dibanding pesaing. 
Pemberian nilai rating untuk variabel kelemahan dan ancaman berkebalikan dengan pemberian nilai rating untuk variabel kekuatan dan peluang dan diberi nilai dari 1 sampai 4 . Semakin kecil nilai kinerja indikator tersebut semakin buruk dibanding pesaing utama.

a. Diberi nilai 1 kalau indikator sangat banyak kelemahannya dibanding pesaing.

b. Diberi nilai 2 kalau indikatornya banyak kelemahannya dibanding pesaing.

c. Diberi nilai 3 kalau indikatornya cukup banyak kelemahannya dibanding pesaing.

d. Diberi nilai 4 kalau indikator kelemahan sedikit dibandingkan pesaing.

Nilai bobot diperoleh berdasarkan hasil nilai bobot dikali nilai rating.

a. Total nilai faktor internal yaitu kekuatan dan kelemahan (IFAS). Apabila nilainya mendekati 4, kekuatan semakin besar dibandingkan kelemahannya. Apabila total nilai mendekati 1, semakin banyak kelemahan dibandingkan kekuatannya.

b. Total nilai faktor eksternal atau peluang dan ancaman (EFAS). Apabila total nilai mendekati 1, semakin banyak ancamannya dibandingkan dengan peluang. Apabila total nilai mendekati 4, artinya semakin banyak peluang dibandingkan ancaman.

Gabungan kondisi internal dan eksternal ini selanjutnya dimasukkan ke dalam Internal External Matrix (analisis keterkaitan dalam matriks SWOT) (Sujoko, 2017), sehingga dapat mengetahui posisi persaingan yang akan terjadi pada perusahaan batubara yang dianalisis. Berdasarkan posisi ini dapat ditentukan strategi yang paling tepat dari sektor batubara untuk menguasai pasar global dibanding negaranegara penghasil batubara anggota WTO lainnya (Tabel 1).

\section{HASIL DAN PEMBAHASAN}

\section{Kondisi Internal Sektor Pertambangan Batubara Indonesia}

Menurut Direktorat Jenderal Minerba (2017), sumber daya batubara Indonesia berjumlah 125,18 miliar ton dan cadangan sebesar 24,24 miliar ton (didominasi kalori sedang $62,83 \%=$ 78,66 miliar ton) dan ini merupakan kekuatan yang cukup besar untuk menghadapi pasar global (Tabel 2).

Tabel 1. Analisis keterkaitan dalam matriks SWOT (internal, external matrix)

\begin{tabular}{|c|c|c|}
\hline \multirow{2}{*}{$\begin{array}{c}\text { FAKTOR EKSTERNAL } \\
\text { (EFAS/External factors } \\
\text { analysis strategic) }\end{array}$} & \multicolumn{2}{|c|}{$\begin{array}{c}\text { FAKTOR INTERNAL } \\
\text { (IFAS/Internal factors analysis strategic) }\end{array}$} \\
\hline & Strengths $(\mathrm{S})$ & Weaknesses (W) \\
\hline Opportunities $(\mathrm{O})$ & $\begin{array}{l}\text { Strategi SO (Maxi-Maxi) } \\
\text { Strategi dengan memanfaatkan kekuatan } \\
\text { (S) untuk mengambil peluang }(\mathrm{O}) \text { dari } \\
\text { lingkungan eksternal. }\end{array}$ & $\begin{array}{l}\text { Strategi WO (Mini-Maxi) } \\
\text { Strategi dalam mengatasi kelemahan }(\mathrm{W}) \\
\text { dengan memanfaatkan peluang }(\mathrm{O}) \mathrm{di} \\
\text { lingkungan eksternal. }\end{array}$ \\
\hline Treats $(\mathrm{T})$ & $\begin{array}{l}\text { Strategi ST (Maxi-Mini) } \\
\text { Strategi dalam memanfaatkan kekuatan } \\
\text { (S) untuk mengatasi ancaman (T) di } \\
\text { lingkungan eksternal. }\end{array}$ & $\begin{array}{l}\text { Strategi WT(Mini-Mini) } \\
\text { Strategi dalam mengatasi kelemahan (W) } \\
\text { dan mengatasi ancaman }(\mathrm{T}) \text { di } \\
\text { lingkungan eksternal. }\end{array}$ \\
\hline
\end{tabular}

Tabel 2. Sumber daya dan cadangan batubara Indonesia

\begin{tabular}{clrc}
\hline No. & \multicolumn{1}{c}{ Provinsi } & $\begin{array}{c}\text { Sumber Daya } \\
\text { (ribu ton) }\end{array}$ & \multicolumn{1}{c}{$\begin{array}{c}\text { Cadangan } \\
\text { (ribu ton) }\end{array}$} \\
\hline 1 & Jawa & $93.410,00$ & - \\
2 & Sumatera & $45.819 .420,00$ & $9.909 .100,00$ \\
3 & Kalimantan & $79.060 .740,00$ & $14.330 .860,00$ \\
4 & Sulawesi & $59.970,00$ & - \\
5 & Maluku Utara & $8.220,00$ & - \\
6 & Papua & $135.840,00$ & - \\
\hline Total & & $125.177 .600,00$ & $24.239 .960,00$ \\
\hline Sumber Direktorat Jenderal Mineral dan Batubara &
\end{tabular}

Sumber : Direktorat Jenderal Mineral dan Batubara (2018) 
Indonesia adalah penghasil batubara yang besar di dunia. Dari 10 negara pemilik cadangan batubara dunia, posisi cadangan Indonesia paling kecil, namun produksinya menempati posisi nomor 5 dunia (melebihi Rusia yang mempunyai cadangan 16\%, Ukraina 3\%, Jerman $4 \%$, Polandia 3\% dan Kazahstan 3\%). Ekspor batubara thermal Indonesia terdiri dari kualitas menengah atau bituminous (5100-6100 kal/gr) dan kualitas rendah (Lignite, < $5100 \mathrm{kal} / \mathrm{gr}$ ) yang sebagian besar importirnya Cina dan India.

Berdasarkan data (Sagawa, 2019), walaupun sumber daya dan cadangan batubara Indonesia cukup besar, tetapi cadangan batubara Indonesia hanya $2 \%$ cadangan dunia, yang menempatkannya pada posisi no. 8 dari 10 negara dengan cadangan batubara terbesar dunia. Posisi cadangan terbesar dunia adalah AS (24\%), Rusia (15\%), Australia (14\%), Cina (13\%), India (9\%), Jerman (4\%), Afrika selatan, Polandia dan Kazakhstan (masing-masing 3\%) dan Indonesia (2\%) seperti terlihat pada Gambar 1 .

Sampai saat ini Indonesia menambang batubara secara besar-besaran dan sebagian besar ditujukan ke pasar global khususnya ke Cina. Selama periode 2013-2017, produksi batubara Indonesia rata-rata mencapai 455,00 juta ton per tahun. Volume ekspor rata-rata mencapai 345,00 juta ton per tahun. Pada periode tersebut harga batubara sedang menurun. Meningkatnya volume ekspor diduga karena pasokan batubara untuk pasar dalam negeri tidak terserap oleh pengguna seperti sektor industri. Sebaliknya permintaan impor dari pasar luar negeri cukup besar. Dengan margin yang relatif kecil pasar ekspor masih lebih menguntungkan dibandingkan pasar domestik. Konsumsi batubara domestik 2013-2017 rata-rata mencapai 97,80 juta ton (14,68\%). Konsumsi 2013 97,00 juta ton, pada 2017 meningkat menjadi 142,00 juta ton (Tabel 3 dan Gambar 2).

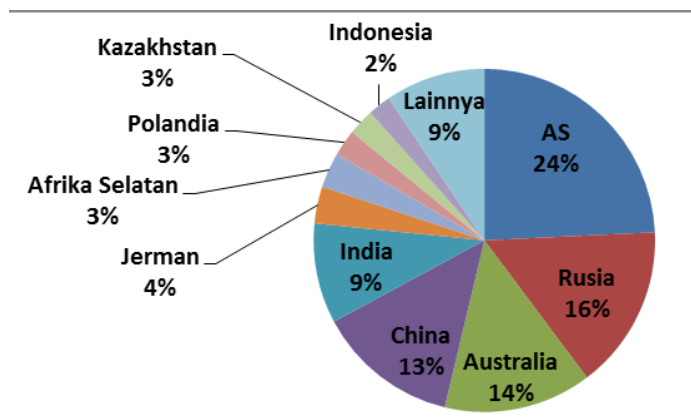

Sumber: Eniscuola Energy \& Environment (2017)

Gambar 1. Posisi cadangan batubara dunia, 2017

Tabel 4 menunjukkan selama periode 20132017 produksi batubara didominasi oleh PKP2B, berkisar antara 59,12\%-63,72\%; sisanya dihasilkan oleh IUP BUMN, IUP PMA, dan IUP Daerah. Selama periode 2013-2017 tersebut, ekspor menurun rata-rata $-4,92 \%$ per tahun. Penurunan ekspor ini sejalan dengan Kebijakan Batubara Nasional (KBN) dan Kebijakan Energi Nasional (KEN) untuk terus mengurangi ekspor dan meningkatkan konsumsi dalam negeri. Hal ini sejalan juga dengan upaya untuk mengurangi penggunaan bahan bakar minyak (fosil) yang cadangannya semakin menipis. Namun ekspor batubara Indonesia tetap masih besar dibandingkan dengan konsumsi domestiknya.

Tabel 3. Produksi, ekspor dan konsumsi batubara Indonesia (2013-2017)

\begin{tabular}{ccccccc}
\hline Tahun & $\begin{array}{c}\text { Produksi } \\
\text { (Juta Ton) }\end{array}$ & $\begin{array}{c}\text { Pertumbuhan } \\
\text { Produksi (\%) }\end{array}$ & $\begin{array}{c}\text { Ekspor } \\
\text { (juta ton) }\end{array}$ & $\begin{array}{c}\text { Pertumbuhan } \\
\text { Ekspor (\%) }\end{array}$ & $\begin{array}{c}\text { Konsumsi } \\
\text { Domestik (juta } \\
\text { ton) }\end{array}$ & $\begin{array}{c}\text { Pertumbuhan } \\
\text { Konsumsi }(\%)\end{array}$ \\
\hline 2013 & 475,00 & - & 356,00 & - & 97,00 & - \\
2014 & 458,00 & $-3,57$ & 383,00 & 7,58 & 77,00 & $-20,61$ \\
2015 & 462,00 & 0,87 & 366,00 & $-4,43$ & 87,00 & 12,98 \\
2016 & 419,00 & $-9,30$ & 333,00 & $-9,01$ & 86,00 & $-1,14$ \\
2017 & 461,00 & 10,02 & 287,00 & $-13,81$ & 142,00 & 95,11 \\
$2013-2017$ & 455,00 & 0,05 & 345,00 & $-4,92$ & 97,80 & 14,68 \\
\hline
\end{tabular}

Sumber : Direktorat Jenderal Mineral dan Batubara (2018) 
Tabel 4. Produksi batubara berdasarkan pelaku usaha, 2013- 2017 (ton)

\begin{tabular}{lccccc}
\multicolumn{1}{c}{ Jenis Izin } & 2013 & 2014 & 2015 & 2016 & 2017 \\
\hline \multirow{2}{*}{ PKP2B } & 290,24 & 291,91 & 276,56 & 269,73 & 278,48 \\
& $(61,20 \%)$ & $(63,72 \%)$ & $(59,86 \%)$ & $(59,12 \%)$ & $(60,37 \%)$ \\
IUP BUMN & 13,60 & 15,62 & 19,06 & 18,78 & 23,38 \\
& $(2,86 \%)$ & $(3,41 \%)$ & $(4,15 \%)$ & $(4,11 \%)$ & $(5,07 \%)$ \\
IUP PMA & - & - & - & 9,27 & 17,60 \\
IUP Daerah & 170,76 & 150,57 & 165,95 & $(2,03 \%)$ & $(3,81 \%)$ \\
& $(35,94 \%)$ & $(32,87 \%)$ & $(35,99 \%)$ & $(34,74 \%)$ & $(30,75 \%)$ \\
\hline Total & 474,60 & 458,09 & 461,57 & 456,19 & 461,25 \\
\hline
\end{tabular}

Sumber: Direktorat Jenderal Mineral dan Batubara (2018).

Keterangan: PKP2B (Perjanjian Karya Pengusahaan Pertambangan Batubara); IUP (Izin Usaha Pertambangan); BUMN (Badan Usaha Milik Negara); PMA (Penanaman Modal Asing).

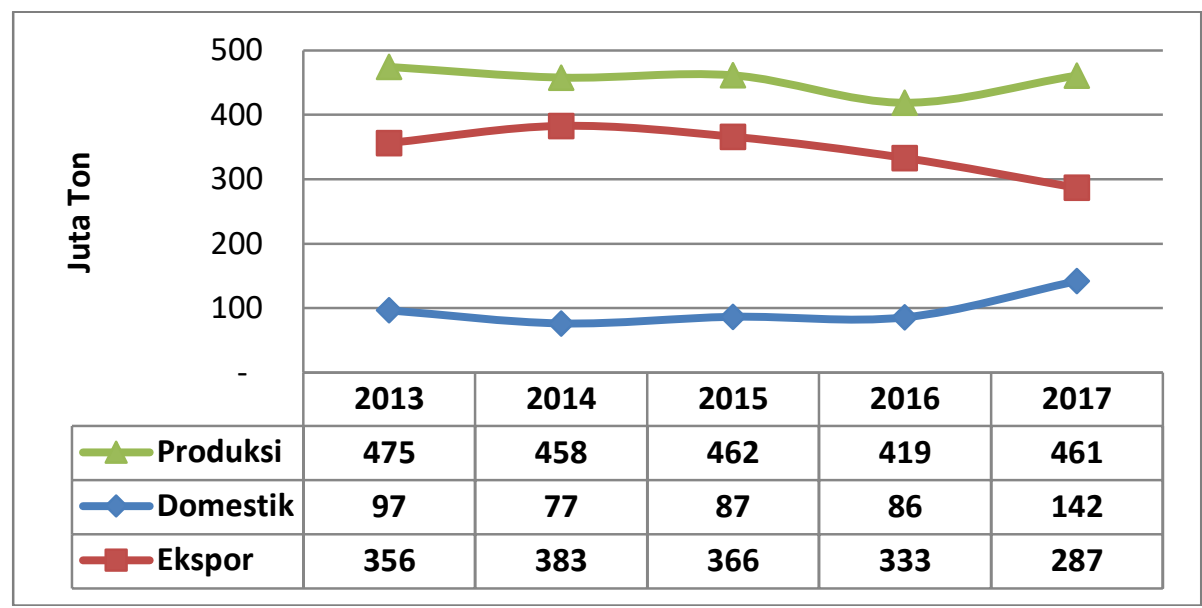

Sumber: Direktorat Jenderal Mineral dan Batubara (2018)

Gambar 2. Grafik produksi, ekspor dan konsumsi batubara Indonesia 2013-2017

Data Direktorat Jenderal Mineral dan Batubara (2018) peningkatan konsumsi domestik batubara dari 97,00 juta ton pada 2013 menjadi 142,00 juta ton pada 2017 terkait dengan program pemerintah membangun PLTU 35.000 MW. Walaupun konsumsi batubara domestik meningkat cukup besar namun industri pengguna di dalam negeri belum sepenuhnya menyerap produksi batubara nasional. Sebagian besar konsumsi domestik diserap oleh PLTU, namun masih kecil dibanding produksi, sehingga ekspor masih besar jika dibandingkan dengan konsumsi domestik.

Selain memiliki sumber daya batubara yang besar, Indonesia juga memiliki jumlah penduduk yang besar dan sebagian besar merupakan usia produktif. Kedua hal tersebut merupakan faktor utama yang membuat Indonesia menjadi pasar potensial di mata investor. Indonesia diproyeksikan menikmati "bonus demografi" dalam periode 2015-2030, yaitu jumlah penduduk produktif lebih besar dari jumlah penduduk non produktif, sehingga akan mendorong tingkat konsumsi dalam negeri (Badan Pusat Statistik, 2018). Pada 2018 jumlah penduduk Indonesia mencapai 266,70 juta atau $3,49 \%$ dari total populasi dunia dan berada di peringkat keempat negara berpenduduk terbanyak di dunia setelah Cina (1,42 miliar jiwa), India (1,37 miliar jiwa), dan Amerika Serikat (328 juta jiwa).

Pertumbuhan penduduk usia produktif itu juga akan secara signifikan ikut mendorong naiknya pertumbuhan ekonomi. Menurut Badan Pembangunan dan Perencanaan Nasional (2015), perkembangan perekonomian nasional untuk periode 2015-2018 tumbuh rata-rata 5,04\% per tahun (2015 sebesar 4,88\%, 2016 sebesar 5,03\%, 2017 sebesar 5,07\% dan 2018 
sebesar 5,17\%). Pertumbuhan PDB dalam jangka pendek ini memberi gambaran perkembangan perekonomian nasional yang cukup baik. Stabilitas pertumbuhan ekonomi perlu dikawal dengan upaya peningkatan teknologi, infrastruktur, ketersediaan energi listrik yang memadai untuk mendukung berjalannya segala aktivitas perekonomian. Pertumbuhan ekonomi yang stabil akan menjadi modal yang kuat bagi Indonesia dalam menghadapi pasar global, namun seluruhnya tergantung dari bagaimana cara pemerintah mengelolanya agar kondisi tersebut dapat dicapai.

Banyaknya investasi yang masuk ke Indonesia membutuhkan persiapan dari pemerintah serta seluruh pemangku kepentingan di sektor pertambangan batubara. Berdasarkan data World Bank (2015) di bidang investasi, Indonesia memiliki iklim investasi yang kondusif. Namun demikian, Indonesia menghadapi berbagai kendala untuk menarik investasi. Pada 2015 Bank dunia mencatat sejumlah permasalahan yang menghambat investasi asing di Indonesia, antara lain: Proses perizinan membutuhkan 1 tahun atau lebih, sedangkan di Vietnam dan Thailand cukup 2 bulan. Pengurusan SNI 4,5 bulan dengan banyak tahapan. Proses impor untuk produksi ekspor mahal dan lama, di atas kertas surat rekomendasi hanya 5 hari tapi dalam praktiknya 6 bulan. Regulasi inkonsisten dan saling bertentangan. Peraturan daerah sering kontra produktif dengan regulasi pemerintah pusat dan diperkirakan ada 1.084 PERDA terkait retribusi dan izin (Jamilus, 2017). Tidak ada entitas (organisasi berbadan hukum tetap) tunggal yang akuntabel untuk memastikan prioritas pemerintah sehingga kalau ada permasalahan bisa menuntut/ mengklaim pihak lain di pengadilan. Dalam masalah penanaman modal asing (PMA) dan divestasi saham juga masih lemah, dampaknya dapat dilihat dengan banyaknya perusahaan tambang batubara besar yang dikuasai oleh pihak asing. Semakin lama sumberdaya batubara yang dimiliki Indonesia akan habis karena batubara merupakan produk yang tidak terbarukan.

Program hilirisasi batubara masih sulit dilaksanakan, disebabkan perkembangan teknologi Indonesia masih jauh di bawah Cina, negara yang sudah berhasil melakukan hilirisasi. Sebenarnya kemampuan SDM
Indonesia untuk menguasai teknologi cukup baik karena banyaknya SDM yang berkualitas dan profesional yang dimiliki Indonesia.

Dalam masalah sosial dan keamanan di Indonesia masih rentan ditandai dengan banyak terjadinya gejolak sosial dan situasi keamanan yang belum dapat dikendalikan terutama di daerah yang kaya akan sumber daya batubara, seperti Sumatera dan Kalimantan. Namun dalam masalah pengelolaan lingkungan pertambangan, reklamasi, penutupan tambang dan rehabilitasi pascatambang, Indonesia dianggap mempunyai kemampuan dan pengalaman yang melebihi negara-negara ASEAN (ASOMM, 2015).

Lemahnya daya saing sektor pertambangan batubara disebabkan sampai saat ini, Indonesia masih menjual batubara dalam bentuk mentah. Program hilirisasi atau peningkatan nilai tambah batubara yang dicanangkan oleh pemerintah melalui Undang-Undang No. 4 tentang Pertambangan Batubara masih belum berjalan. Menurut para pengusaha hal ini disebabkan karena infrastruktur (dermaga, jalan, pelabuhan) untuk mendukung peningkatan nilai tambah batubara belum memadai. Selain itu, pangsa pasar batubara Indonesia juga hanya 4 negara utama. 40\%, ditujukan ke Cina dan sisanya ditujukan India, Korea dan Jepang. Apabila terjadi gejolak ekonomi atau perubahan kebijakan energi yang terkait dengan batubara di Cina, akan menimbulkan permasalahan terhadap sektor pertambangan batubara Indonesia.

Di bidang pelaksanaan hukum (law enforcement) yang terkait dengan sektor pertambangan batubara sangat lemah, ditandai belum berjalannya Undang-Undang No. 4 tahun 20019 tentang hilirisasi mineral dan batubara yang sudah 11 tahun lebih masih belum berjalan. Untuk itu pemerintah melakukan perubahan Undang-Undang pertambangan tentang mineral dan batubara dengan Undang-Undang No. 3 Tahun 2020.

Dalam birokrasi, Indonesia masih memiliki masalah perizinan yang lama dan berbelit-belit. Semua kondisi tersebut menyebabkan daya saing produk Indonesia sangat lemah serta menjadi penghambat dalam menarik investor yang mau menanamkan modalnya di Indonesia. Langkah pemerintah diperlukan untuk 
mengatasi persoalan ini, yaitu dengan berusaha memangkas jalur perizinan agar lebih mudah.

\section{Kondisi Eksternal Sektor Pertambangan Batubara Indonesia}

Kondisi eksternal yang merupakan peluang bagi sektor pertambangan batubara, antara lain jumlah penduduk dunia setiap tahunnya semakin bertambah. Berdasarkan Energy Outlook yang dikeluarkan BPPT (Yudiartono, Anindhita, Sugiyono, Wahid dan Adiarso, 2018), saat ini jumlah penduduk dunia sudah mencapai 7,5 miliar lebih. Semakin banyak penduduk dunia, maka kebutuhan energi akan semakin besar dan penggunaan energi dunia ke depan akan didominasi oleh batubara. Hal ini disebabkan karena menipisnya cadangan minyak dunia sehingga memberikan peluang lebih besar bagi batubara sebagai substitusi minyak.

Selain jumlah penduduk dunia, peluang yang memengaruhi sektor pertambangam batubara adalah pertumbuhan ekonomi dunia yang fluktuatif. World Bank (2015) memproyeksikan pertumbuhan ekonomi dunia 2019-2024, akan merosot pada tingkat 3-3,2\% karena banyak tantangan terutama bagi negara-negara berkembang dan terjadinya pandemi Covid-19. Namun kebutuhan energi dunia masih stabil.

Peluang lainnya, kerjasama dengan negara maju seperti Cina untuk alih teknologi dan pengetahuan. Kerjasama tersebut juga dapat meningkatkan upaya riset dan teknologi serta investasi bidang energi batubara. Alih teknologi dan pengetahuan dengan Cina diharapkan dapat menciptakan SDM yang berkualitas dan profesional di sektor pertambangan batubara, dan mampu mendorong perbaikan alokasi sumber daya produksi (modal, SDM, mesin) kepada kegiatan-kegiatan yang lebih produktif (Akbar, Kholil dan A., 2015). Globalisasi ekonomi pada akhirnya akan menjadi peluang atau ancaman bagi Indonesia, bahkan dapat mengintervensi kepentingan nasional dan pihak asing bisa memengaruhi perumusan kebijakan dalam negeri.

\section{Analisis IFAS dan EFAS}

Analisis yang digunakan adalah model SWOT dengan menyusun matriks yang terdiri dari komponen lingkungan internal atau internal factors analysis strategic (IFAS) dan unsur lingkungan eksternal atau external factors analysis strategic (EFAS). IFAS memberikan gambaran tentang kelemahan dan kekuatan sektor pertambangan batubara, sementara EFAS memberikan gambaran tentang peluang dan ancaman dari yang akan membangun atau meruntuhkan pelaksanaan misi perusahaan (Budin dan Lianto, 2016). Melalui matriks IFAS dan EFAS, kompleksitas permasalahan dapat diidentifikasi sehingga memudahkan menyusun strategi untuk memanfaatkan kekuatan dalam meraih peluang, sekaligus meminimalkan kelemahan dan mengatasi ancaman di lingkungan ekonomi global (Dayani, Pribadiono dan Noviandari, 2017). Hasil perhitungan IFAS dan EFAS serta Matriks Analisis Keterkaitan SWOT ditunjukkan pada Lampiran 1, 2 dan 3.

\section{KESIMPULAN DAN SARAN}

\section{Kesimpulan}

Indonesia memiliki posisi penting dalam percaturan supply dan demand batubara dunia sehingga akan menentukan harga komoditas ini di pasar global. Alih teknologi, baik berupa gasifikasi batubara, coal upgrading maupun teknologi batubara lainnya dapat dilakukan antara lain melalui kerjasama dengan Cina. Dengan demikian pertambangan batubara diharapkan lebih kompetitif dibanding negaranegara produsen batubara lainnya sesama negara-negara anggota WTO.

\section{Saran}

Di samping kerjasama dengan negara lain untuk peningkatan kualitas dan daya saing batubara nasional, langkah strategis yang perlu dilakukan adalah:

a. Meningkatkan peran riset dan teknologi pengolahan sumber daya batubara melalui peningkaan kualitas SDM untuk mengejar perkembangan teknologi pengolahan batubara sehingga nilai tambah meningkat.

b. Meningkatkan pembangunan infrastruktur pendukung batubara melalui kerjasama lintas sektoral.

c. Penyederhanaan regulasi di berbagai sektor yang membutuhkan batubara sehingga meningkatnya investasi akan berdampak langsung dan tidak langsung dengan 
permintaan batubara domestik yang tidak terserap oleh ekspor.

d. Menciptakan lingkungan sosial dan keamanan yang kondusif bagi kegiatan pertambangan batubara.

\section{UCAPAN TERIMAKASIH}

Penulis mengucapkan terimakasih kepada Dinas Pertambangan dan Energi Provinsi Kalimantan Timur, Provinsi Kalimantan Selatan dan Provinsi Sumatera Selatan dan juga kepada PT. Trubaindo Coal Mining, PT. Bharinto Ekatama, PT. Golden Great Borneo, PT. Duta Alam Sumatera, PT. Sungai Danau Jaya dan KUD Karya Murni yang telah membantu memberikan data terkait dengan masalah sektor pertambangan batubara. Di samping itu penulis juga mengucapkan terimakasih kepada rekanrekan atas bantuan data permasalahan ekonomi baik nasional (domestik) maupun internasional (WTO) yang telah memperkaya tulisan ini.

\section{DAFTAR PUSTAKA}

Agustiwi, A. (2016) "Hukum sebagai instrumen politik dalam era globalisasi," Jurnal Rechtstaat Nieuw, 1(1), hal. 45-57.

Akbar, M. S., Kholil, M. dan A., R. (2015) "Analisa strategi pemasaran terhadap performance kerja dengan menggunakan metode analisis SWOT," RATIH: Jurnal Rekayasa Teknologi Industri Hijau, 1(1), hal. 1-14.

Almahdy, I. dan Imam Mustaqim, M. (2011) "Perancangan strategi berbasis SWOT pada industri tambang batubara," Jurnal PASTI, 4(2), hal. 1-17.

Anwar, M. C. dan Utami, M. C. (2012) "Analisis SWOT pada strategi bisnis dalam kompetisi pasar (Studi kasus: Toko pojok Madura)," Studia Informatika: Jurnal Sistem Informasi, 5(1), hal. 1-9.

ASOMM (2015) ASEAN Senior Official Meeting on Mineral (ASOMM). Bali.

Azzarqa dan Basuki, U. (2014) “Peranan pemerintah daerah melindungi produk lokal menghadapi globalisasi," Jurnal Hukum Islam dan Bisnis, 6(1), hal. 67-82.

Badan Pembangunan dan Perencanaan Nasional (2015) Perkembangan ekonomi Indonesia dan dunia. Jakarta: Penerbit Deputi Bidang Ekonomi Bappenas.

Badan Pusat Statistik (2018) Statistik Indonesia 2018. Diedit oleh Subdirektorat Publikasi dan Kompilasi Statistik. Jakarta: Badan Pusat Statistik.

Bahari, H., Leksono, E. B. dan Ismiyah, E. (2018) "Pendekatan risk managment \& analisis SWOT untuk mengantisipasi penurunan laba di ECOS minimarket Gresik," Jurnal MATRIK, XVIII(2), hal. 23-40.

BP (2018) BP statistical review of world energy 2018. 67 ed. BP.

Budin dan Lianto (2016) "Analisis SWOT pada credit union Mura Kopa di Balai Karangan," MABIS, 7(2), hal. 81-97.

Dayani, D., Pribadiono dan Noviandari, I. (2017) "Analisis SWOT sebagai strategi pengembangan usaha pada aspek operasional perusahaan pada PT. Indo Caliplast," Jurnal Manajemen Branchmark, 3(3), hal. 180-193.

Direktorat Jenderal Mineral dan Batubara (2018) Laporan kinerja 2017. Jakarta: Direktorat Jenderal Mineral dan Batubara.

Eniscuola Energy \& Environment (2017) World coal reserves in 2017, eniscoula.net. Tersedia pada: http://www.eniscuola.net/en/mediateca/world -coal-reserves-in-2017/ (Diakses: 1 Desember 2020).

Firmansyah, H. dan Hendra, E. (2015) "Implikasi globalisasi ekonomi dan perdagangan bebas terhadap stabilitas nilai rupiah," Asy-Syari'ah, 17(2), hal. 45-54. doi: 10.15575/as.v17i2.648.

Gunawan, G. M. (2013) “Manajemen dan pengembangan operasional tambang batubara pada PT. Tri Eka Bersama," Jurnal AGORA, 1(1), hal. 1-9.

Hidayat, R. dan Rahmat, R. (2018) "Analisis SWOT sebagai dasar keputusan atrategi pemasaran pada perusahaan server pulsa di Kota Batam (Studi kasus pada CV. Star Pratama)," JOURNAL OF APPLIED BUSINESS ADMINISTRATION, 2(1), hal. 94-108. doi: 10.30871/jaba.v2i1.745.

Istiqomah dan Andriyanto, I. (2017) “Analisis SWOT dalam pengembangan bisnis (Studi kasus pada sentra jenang di Desa Wisata Kaliputu Kudus)," Jurnal Bisnis dan Manajemen Islam, 5(2), hal. 363-382.

Jamilus (2017) "Analisis fungsi dan manfaat WTO bagi negara berkembang khususnya Indonesia," JIKH, 11(2), hal. 205-225. 
Kusumawardhana dan Zulkarnain, I. (2016) "Globalisation and strategy: Negara, teritori dan kedaulatan di era globalisasi," Jurnal IImu dan Budaya, 40(54), hal. 6139-6160.

Mahsun, A. (2013) "Pendidikan Islam dalam arus globalisasi: Sebuah kajian deskriptif analitis," Epistemé: Jurnal Pengembangan IImu Keislaman, 8(2), hal. 259-278. doi: 10.21274/epis.2013.8.2.259-278.

Nawatmi, S. (2011) "Globalisasi dan inflasi," Dinamika Keuangan dan Perbankan, 3(1), hal. 88-101.

Nurhaidah dan Musa, M. I. (2015) “Dampak pengaruh globalisasi bagi kehidupan Bangsa Indonesia," Jurnal Pesona Dasar, 3(3), hal. 114.

Parimin dan Putra, M. U. M. (2018) "Perekonomian Indonesia dalam era globalisasi ASEAN," Jurnal Wira Ekonomi Mikroskil, 8(1), hal. 1-12.

Putra, R. dan Saraswati, R. (2016) "Politik hukum Pancasila dalam menghadapi arus globalisasi (Pengaruh globalisasi ekonomi terhadap proses ratifikasi charter of the association of Southeast Asian Nations Menjadi Undang-Undang Nomor 38 Tahun 2008 Tentang Pengesahan Piagam ASEAN)," LAW REFORM, 12(2), hal. 256-265. doi: 10.14710/Ir.v12i2.15878.

Rahmayati (2015) "Analisis SWOT dalam menentukan strategi pemasaran udang beku PT. Mustika Mina Nusa Aurora, Tarakan Kalimantan Utara," Jurnal Galung Tropika, 4(1), hal. 60-67.

Sagawa, A. (2019) "Outlook for coal market in 2019," in The 431st Forum on Research Works IEEJ. Japan: The Institute Of Energy Economics, hal. 1-14.

Siregar, Y. H. I. dan Sunarti, S. (2017) "Analisis strategi pemasaran untuk meningkatkan volume penjualan ekspor (Studi kasus pada perusahaan PT. Kaltim Prima Coal)," Jurnal Administrasi Bisnis, 42(1), hal. 36-45.

Subaktilah, Y., Kuswardani, N. dan Yuwanti, S. (2018) "Analisis SWOT: Faktor internal dan eksternal pada pengembangan usaha gula merah tebu (Studi kasus di UKM Bumi Asih, Kabupaten Bondowoso)," JURNAL AGROTEKNOLOGI, 12(02), hal. 107-115. doi: 10.19184/j-agt.v12i02.9276.
Sujati, B. (2018) "Sejarah perkembangan globalisasi dalam dunia Islam," NALAR: Jurnal Peradaban dan Pemikiran Islam, 2(2), hal. 98-109. doi: 10.23971/njppi.v2i2.969.

Sujoko, E. (2017) "Strategi peningkatan mutu sekolah berdasarkan analisis SWOT di Sekolah Menengah Pertama," Kelola: Jurnal Manajemen Pendidikan, 4(1), hal. 83-96. doi: 10.24246/j.jk.2017.v4.i1.p83-96.

Sumitro (2015) "Globalisasi ekonomi syariah di Indonesia dan perannya terhadap UMKM," Jurnal Samudra Ekonomi dan Bisnis, 6(1), hal. 48-61.

Suprijanto, A. (2011) "Dampak globalisasi ekonomi terhadap perekonomian Indonesia," Jurnal IImiah CIVIS, I(2), hal. 100-119.

Tamara, A. (2016) "Implementasi analisis SWOT dalam strategi pemasaran produk mandiri tabungan bisnis," Jurnal Riset Bisnis dan Manajemen, 4(3), hal. 395-406.

Triono (2013) "Pengaruh globalisasi terhadap perdagangan perempuan Indonesia," Jurnal TAPIs, 9(1), hal. 83-98.

Wicaksono, A. (2018) "Strategi pemasaran dengan menggunakan analisis SWOT tanpa skala industri pada PT X di Jakarta," Jurnal Manajemen Industri dan Logistik, 1(2), hal. 192-201. doi: 10.30988/jmil.v1i2.19.

Widayanto, S. (2016) "WTO melindungi kepentingan domestik negara anggotanya secara optimal," Jurnal Tinjauan Perdagangan Indonesia, 35, hal. 1-16.

World Bank (2015) "Gross national income percapita 2015, more than 217 countries," in World Development Indicator Database. World Bank, hal. 625.

Yudiartono, Anindhita, Sugiyono, A., Wahid, L. M. A. dan Adiarso (ed.) (2018) Outlook energi Indonesia: Energi berkelanjutan untuk transportasi darat. Jakarta: PPIPE dan BPPT.

Zaroni, A. N. (2015) "Globalisasi ekonomi dan implikasinya bagi negara-negara berkembang : Telaah pendekatan ekonomi Islam," ALTIJARY, 1(1), hal. 1-22. doi: 10.21093/at.v1i1.418. 

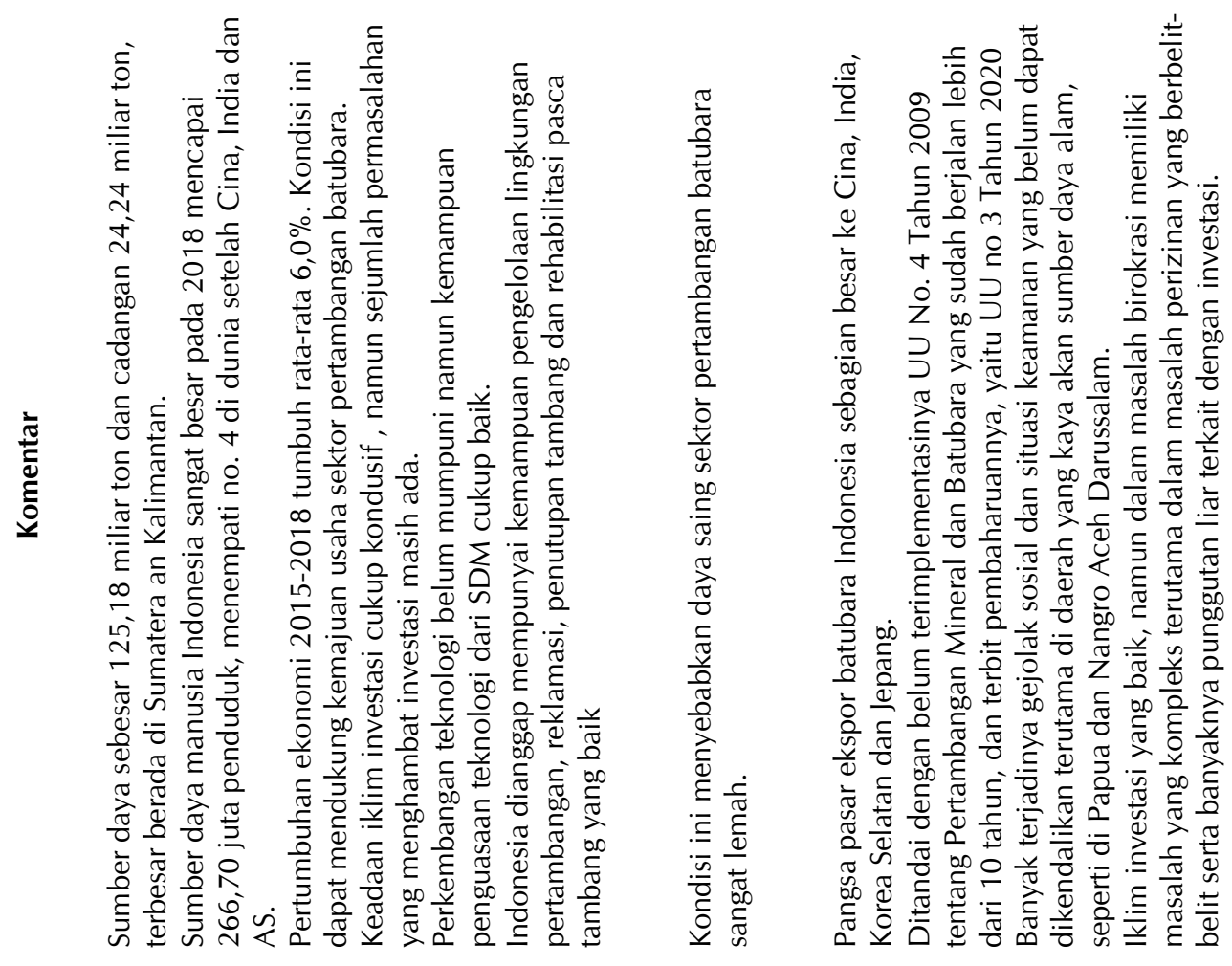

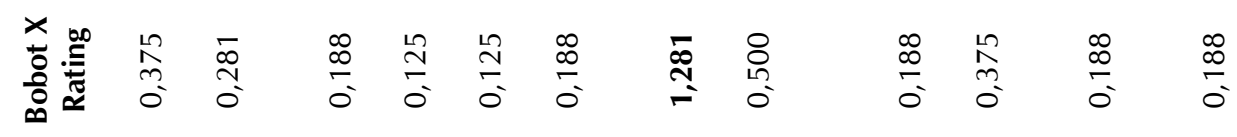

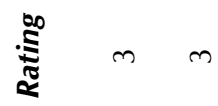

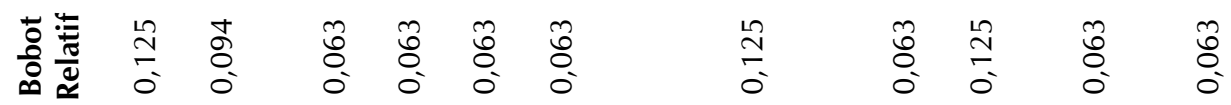

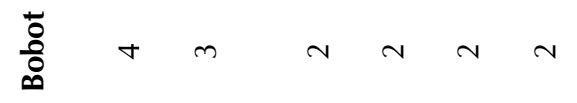

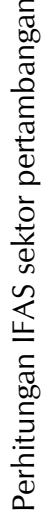

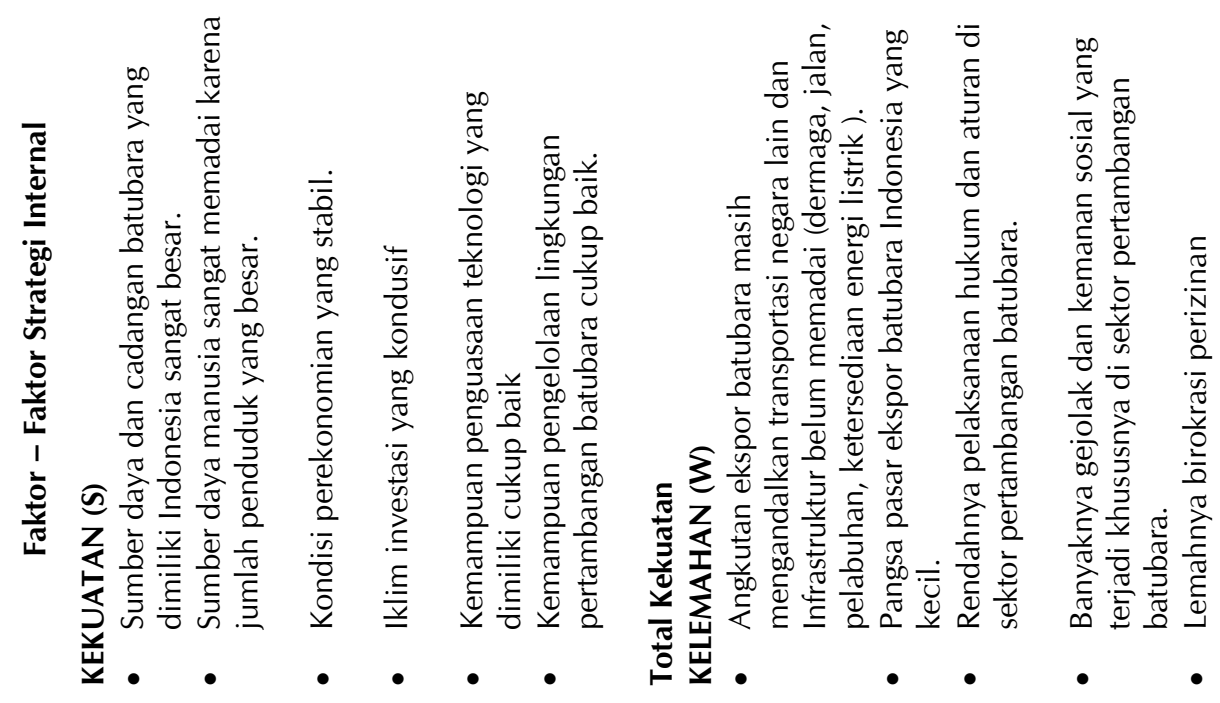


Pengelolaan Sumberdaya Batubara Indonesia dan Prospeknya dalam Pasar Global ... Harta Haryadi

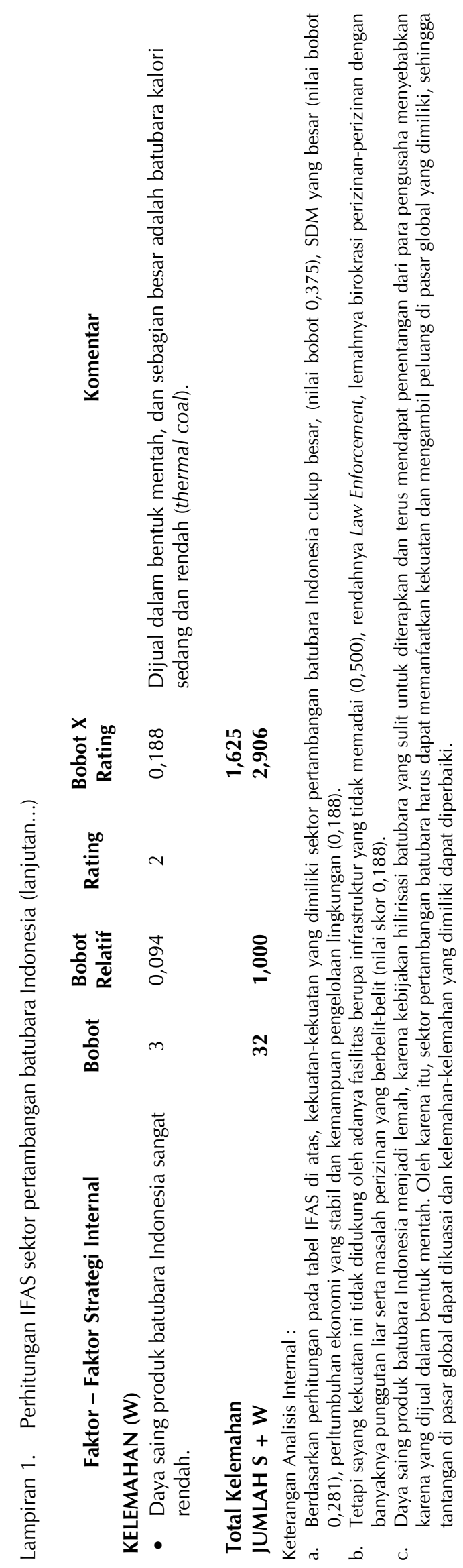



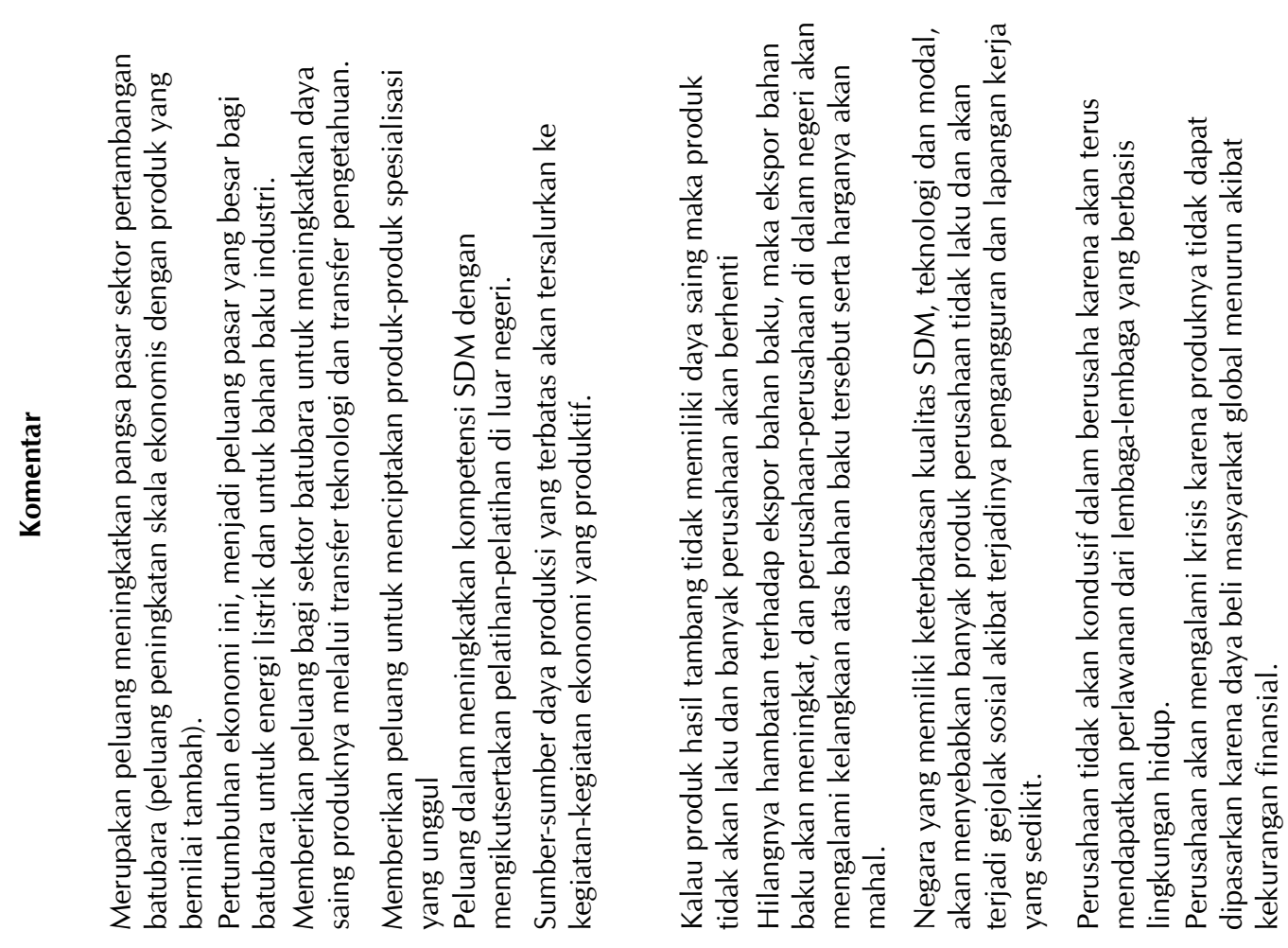

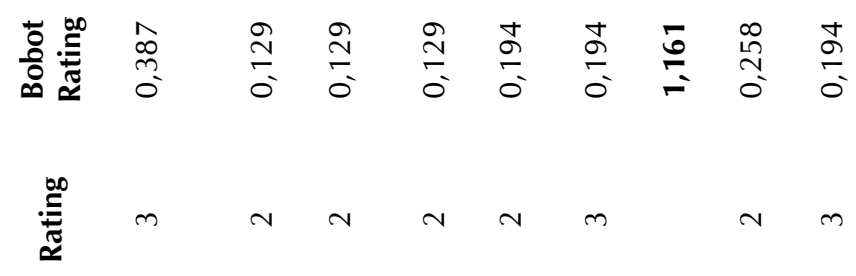

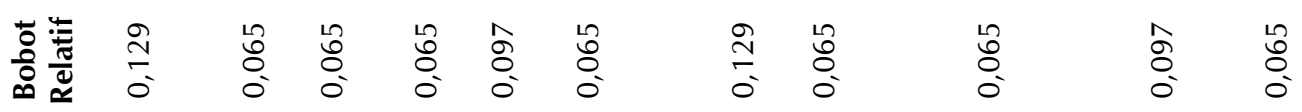
융

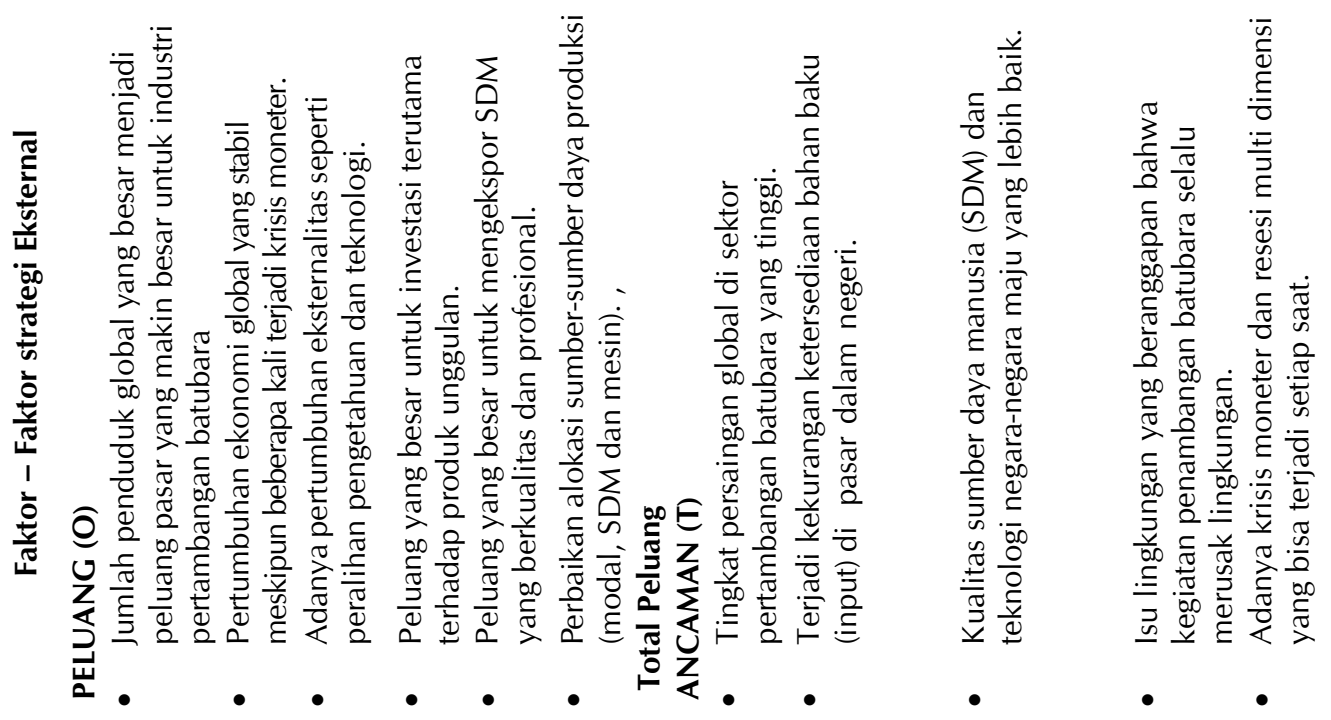


Pengelolaan Sumberdaya Batubara Indonesia dan Prospeknya dalam Pasar Global ... Harta Haryadi
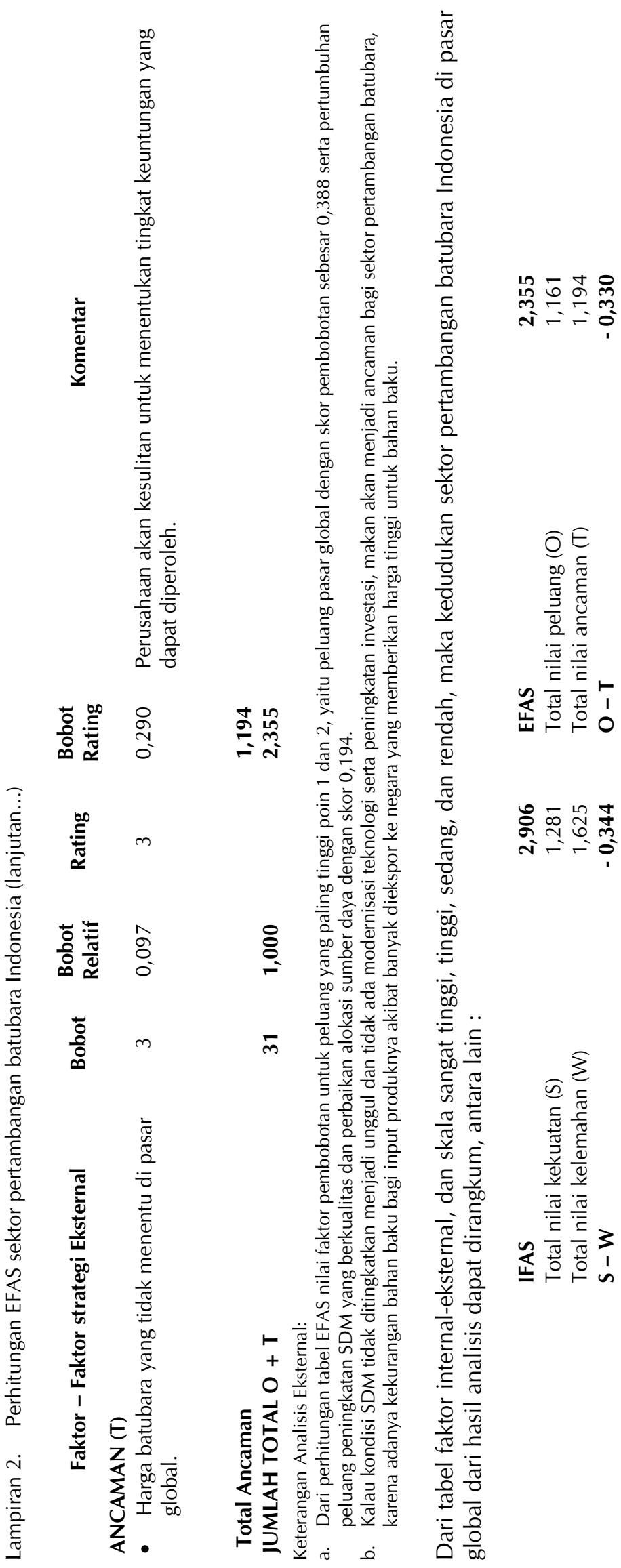


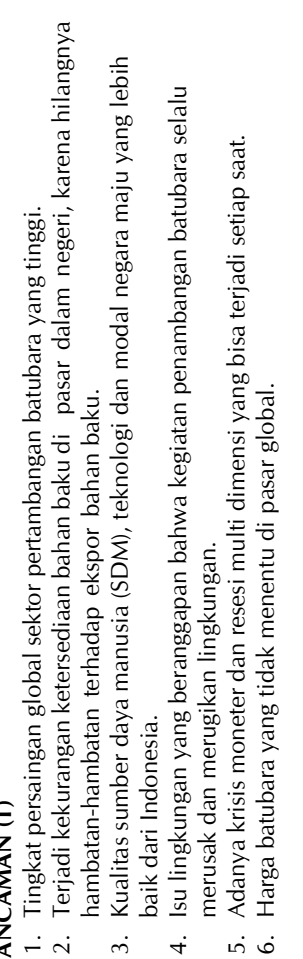

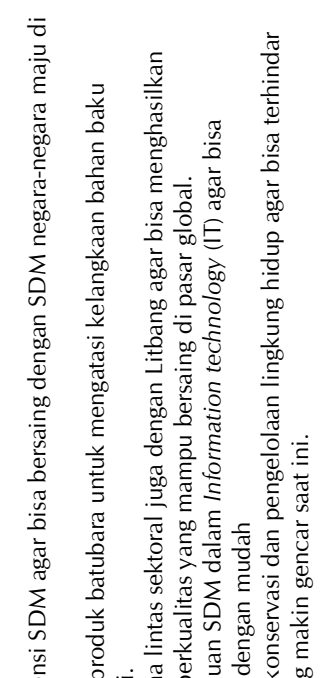

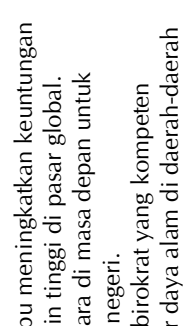

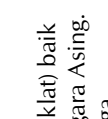

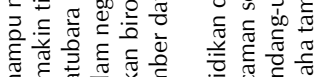

E

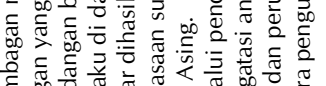

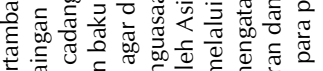

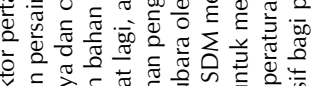

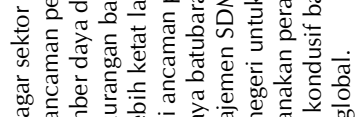
$\mathcal{S}$

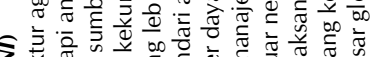

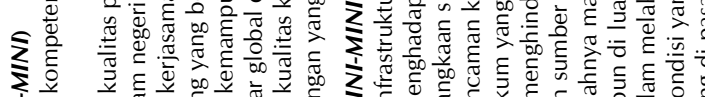

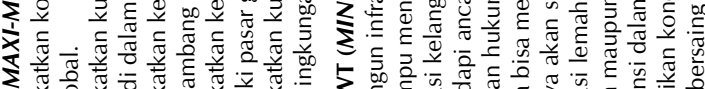

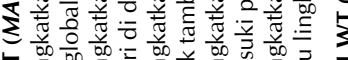

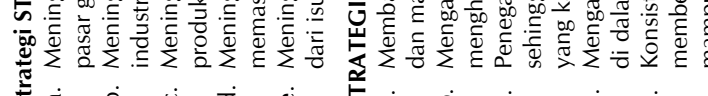

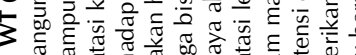

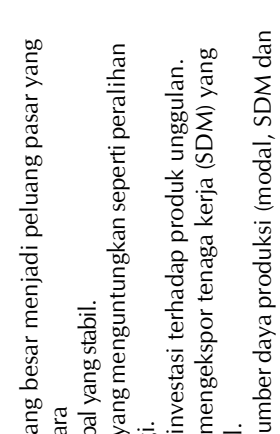

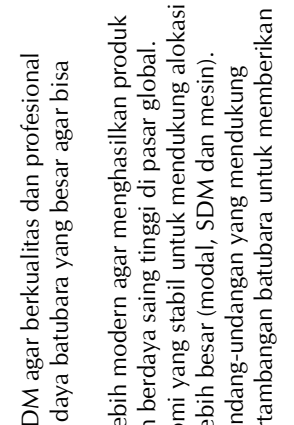

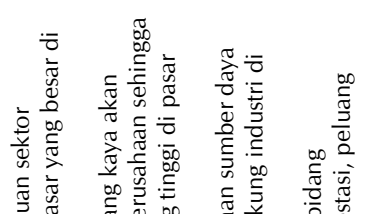

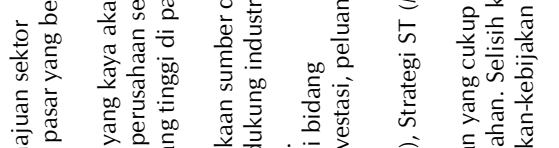

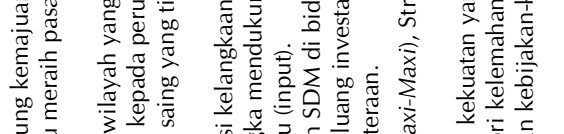

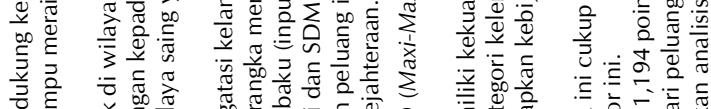

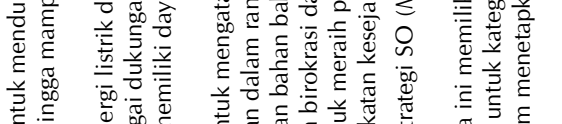

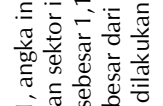

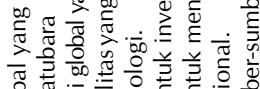

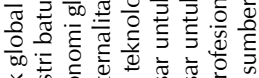

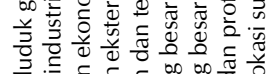

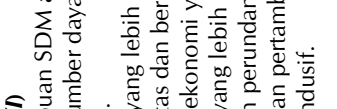
美

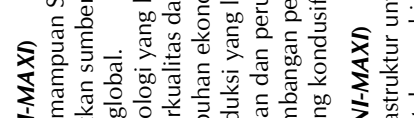

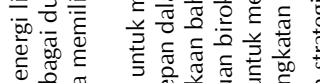

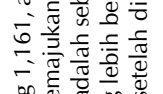

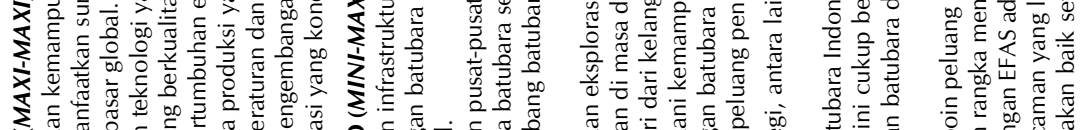

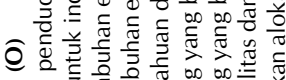

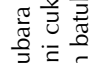

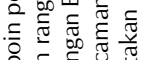

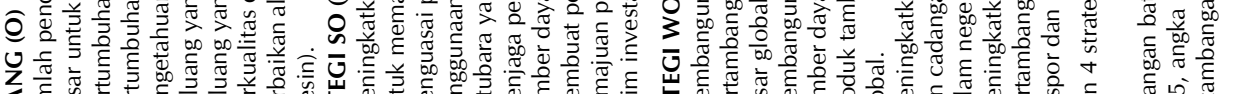

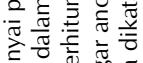

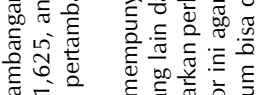

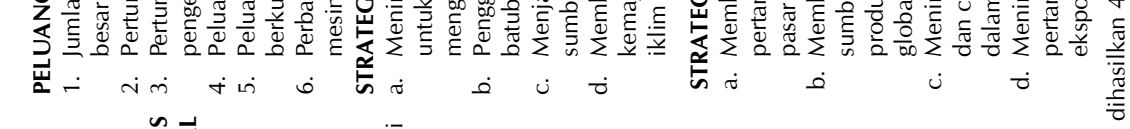

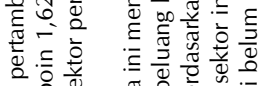

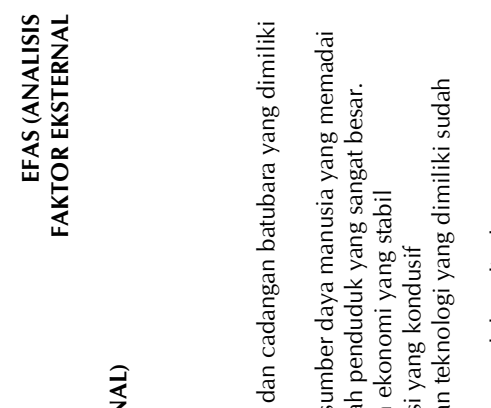

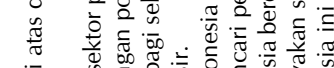

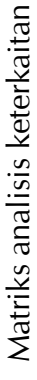

音

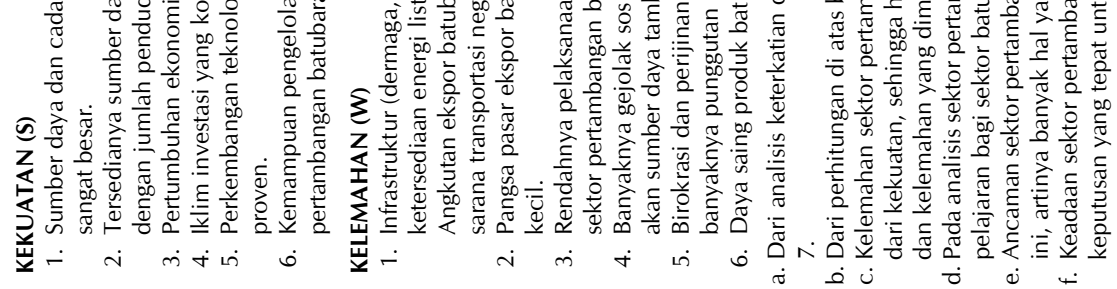

